\title{
Fire Risk Assessment of Low Cost High Rise Residential Buildings in Kuala Lumpur: A Case Study
}

\author{
Farid Wajdi Akashah*, Timothy Kurannen Baaki, and Shing Peng Lee \\ Centre for Building, Construction and Tropical Architecture (BuCTA), Faculty of Built \\ Environment, University of Malaya (UM), 50603 Kuala Lumpur, Malaysia. \\ *faridakashah@um.edu.my
}

Low cost high rise residential buildings have had the highest number of fire incidents compared to other types of buildings in Malaysia. This study aims to determine the fire risk status of low cost high rise residential buildings in Kuala Lumpur through a fire risk assessment (FRA) approach. The study forms the exploratory phase of a wider research to develop a fire risk indexing (FRI) methodology for low cost high rise residential buildings in Kuala Lumpur. On-site fire audits were performed on three (3) selected low cost high rise residential buildings in the Pantai area of Kuala Lumpur using a 10-item FRA checklist. The results showed that all 10 FRA criteria recorded multiple issues ranging from the presence of multiple ignition and fuel sources to inadequate or vandalized firefighting equipment to lack of training of occupants on fire risk and safety. Further analysis showed that the fire risk status of the observed buildings was 'high'. A need for immediate intervention measures to improve the fire safety credentials of the observed case study buildings was established. Recommendations include reconsidering the design layout of rooms, improving active and passive fire safety protection systems, and training of occupants to improve their awareness on fire safety.

Keywords: Fire risk assessment, fire safety, high rise, low cost housing, Malaysia, residential buildings

\section{INTRODUCTION}

The government of Malaysia continues to provide affordable public housing for those with low-income status as demand for this type of housing remains very high especially in the country's most urbanized and vibrant city Kuala Lumpur (Aini, Murni, \& Aziz, 2016). According to the Ministry of Housing and Local Government, the number of persons applying to rent or purchase affordable residential housing rose more than $50 \%$ in just a year to 20,426 in 2010 from 13,529 in 2009 (National Housing Department, 2010). In the Tenth Malaysia Plan the government expressed its commitment to continue to provide affordable housing nationwide. Between 1990 and 2009 , the government provided an average of 40,400 low cost housing units a year with another 47,800 between 2011 and 2015, showing a significant increment of roughly $18 \%$ from 2011 (The Economic Planning Unit, 2010). From this scenario of increasing demand for affordable housing in country provision of particularly high rise low cost residential housing will continue to be on the rise especially in big cities such as Kuala Lumpur. To minimise fire hazard to low levels practically possible, Chu, Chen, Sun, \& Sun
(2007) suggest that a comprehensive assessment of the type and structural design of buildings as well as human behaviour is necessary. In this vein, Yatim (2009) maintains that, compared to other building types, high rise residential buildings pose higher fire risk due to factors such as multiple households with different levels of education, cultural backgrounds and lifestyle. In the event of a fire, Kobes, Helsloot, Vries, \& Post (2010) note that, the survival of the building occupants is largely dependent on the nature of the fire, human aspects and building features. Kobes et al. (2010) also maintain that occupants' personal characteristics such as knowledge, experience and alertness to fire hazard will typically affect how occupants respond and perform in the event of a fire.

In Malaysia, low cost high rise residential buildings have recorded the most number of fire incidents compared to other types of buildings. While these types of buildings pose higher fire risk, there have been little fire safety research focusing on these types of buildings in Malaysia. This study therefore aims to evaluate fire risk in low cost high rise residential buildings - Peoples' Housing Program (PHP) buildings in Kuala Lumpur, Malaysia. The 
objective is to establish the extent of fire safety protection as well as determine the fire risk status of selected PHP buildings in Kuala Lumpur. This study forms the exploratory phase of a wider research attempting to develop a fire risk indexing (FRI) methodology for low cost high rise residential buildings in Kuala Lumpur, Malaysia.

\section{LITERATURE REVIEW}

\subsection{Fire safety issues in low cost high rise residential buildings in Malaysia}

The exact definition of high rise buildings varies across different countries and regions. For instance, according to the Ministry of Housing, Spatial Planning, and the Environment, Netherlands (2005), a high rise building is a multi-storey building consisting more than four storeys. Others describe high rise buildings as buildings exceeding 75 feet (Craighead, 2009; International Code Council, 2009; Hall, 2013; Solomon \& Harrington, 2003). In Malaysia, a building with a height exceeding $18.3 \mathrm{~m}$ is considered to be a high rise building following the Uniform Building ByLaws 1984 (Laws of Malaysia, 2012).

Low cost housing also known as 'flats' is classified into two types namely Public Housing (PH) or Perumahan Awam (PA) and People's Housing Program (PHP) or Projek Perumahan Rakyat (PPR). Public Housing was established in early 1960's by the Ministry of Housing and Local Government to accommodate those in the local low-income bracket in the country, i.e., people earning RM1,500/month (approx.USD361/month) or less (Goh \& Ahmad, 2011). The Peoples Housing Program on the other hand, was established in 1998 by the National Economic Action Council to relocate people from squatter accommodations in response to the Squatter Relocation Project launched in 1996. The objective of the Squatter Relocation Project had been to eradicate squatter accommodations by the year 2005 through the provision of affordable housing at the rate of RM124/month (approx. USD30/month) per housing unit. All PHP buildings have been provided in three bedrooms per housing unit with a minimum floor area of $650 \mathrm{ft}^{2}$ (Kuala Lumpur City Hall, 2008).
Retaining the number of low-cost houses is important towards the provision of accommodation for transient inhabitants and people in the low-income bracket who constitute about $1.5 \%$ of total population in the city of Kuala Lumpur (KLCH, 2008). Since it is apparent that the provision of high rise low cost housing with continue to rise, existing issues such as the low quality of materials used and adoption of unskilled foreign labour, lack of control, coordination, implementation and compliance to the existing rules and regulations in the National Housing Policy need to be resolved in order for the housing sector to remain a constant contributor to the economic growth of the nation as well as achieving quality construction in the built environment (National Housing Department, 2010). Beyond the emphasis on the nation's economic growth technology enhancement in the built environment, there is need to recognise the importance of knowledge and perception of occupants regarding fire risk and building fire to ensure both the safety of life and property in the event of fire emergencies. Statistics show that low cost high rise residential buildings in Malaysia have recorded the highest number of fire incidents among all buildings types. According to the Fire and Rescue Department of Malaysia (FRDM), between 2012 and October 2014, 480 fire incidents were recorded in low cost high rise residential buildings in Kuala Lumpur, a substantially higher amount compared to apartments/condominiums, the building type with the next highest fire incidents (FRDM, 2016) (see Table 1).

These statistics suggests a disturbing scenario with fire safety scenario in low cost high rise residential buildings. According to FRDM, majority of the fires were caused by failure of electrical wiring systems and open flames. The failure of electrical wiring system consisted of short-circuiting and overloading of electrical devices while open flame fires came from disposed cigarettes, burning of candles, mosquito repellent incense, matches and others. With continued rise in demand and government commitment to providing affordable housing, more low-cost housing projects are going to the executed.

Table 1: Fire incidents according to different buildings types in Kuala Lumpur

\begin{tabular}{lllll}
\hline Building types & 2012 & 2013 & $\begin{array}{l}\text { Until } \\
2014\end{array}$ & $9^{\text {th }}$ Oct., \\
\hline Terrace house & 74 & 98 & 58 & 230 \\
\hline
\end{tabular}




\begin{tabular}{lllll}
\hline Flat (low cost high rise) & $\mathbf{1 3 2}$ & $\mathbf{2 0 0}$ & $\mathbf{1 4 8}$ & $\mathbf{4 8 0}$ \\
Apartment/condominium & 93 & 118 & 95 & 306 \\
Squatter & 10 & 28 & 17 & 55 \\
Long house/traditional & 5 & 5 & 0 & 10 \\
house & & & \\
\hline
\end{tabular}

Source: FRDM (2016)

However, this objective cannot be met at the expense of providing adequate fire safety systems within these types of buildings as it is essential for the safety of those occupying these types of accommodation.

\section{METHODS}

\subsection{Fire Risk Assessment (FRA) approach}

One way of establishing the fire risk status of a building is through a Fire Risk Assessment (FRA). FRA requires a building be subjected to fire safety audit which involves an assessment of both the adequate presence and working conditions of active and passive fire protection systems, usually against relevant guidelines and standards such as Uniform Building By-Laws (UBBL) 1984, Malaysian Standard (MS) and the British Standard (BS). According to the BS8800:1996 Guide to Occupational Health and Safety Management Systems, FRA is defined as the process of assessing the severity of fire risk and deciding whether or not the risk is acceptable or not. FRA means the evaluation of the potential fire hazards to human and property as well as the ability to contain and escape injury in the event of a fire (Yung, 2008). It involves the assessment of the probability of fire occurring (hazard) and the impact of a fire occurrence and is expressed as:

$$
\begin{aligned}
& \text { Risk }=p x i \\
& \text { where; } \mathrm{p}=\text { probability } \\
& \mathrm{i}=\text { impact }
\end{aligned}
$$

FRA is an essential part of fire risk management. It is not only a tool for assisting the understanding of fire hazards present in a building but also provides remedial actions to be undertaken (Dawkin, 2001; Reyers, 2003) Kaplan \& Watts (2001) also maintains that it is important to assess fire risk in buildings in order to establish the consequences of the fire safety level. A detailed and comprehensive fire risk assessment should therefore be performed to safeguard the building safety and to determine suitability of remedial actions (Reyers, 2003).

\subsubsection{Framework of FRA used in this study}

A modified FRA checklist from the Department for Communities and Local Government, UK, that is based on a five-stage FRA framework (see Figure 1) was used to perform a fire safety audit in the case study PHP buildings. Fire risk in the case study buildings was then evaluated based on the probability and impact of each individual element of the modified checklist. The checklist originally contained 9 items and was modified to include one more item to assess disabled persons consideration as shown in Figure 2. The overall fire risk status of the case study buildings was calculated based on the evaluation matrix of both likelihood and severity of fire occurrence as shown in Table 2 to Table 4.

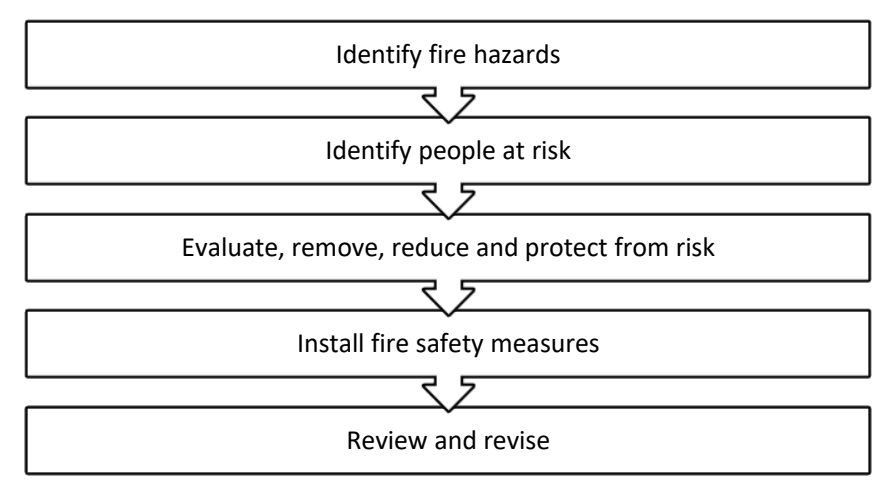

Figure 1: The five stages of FRA

Source: Billington, Copping, \& Ferguson (2008) 


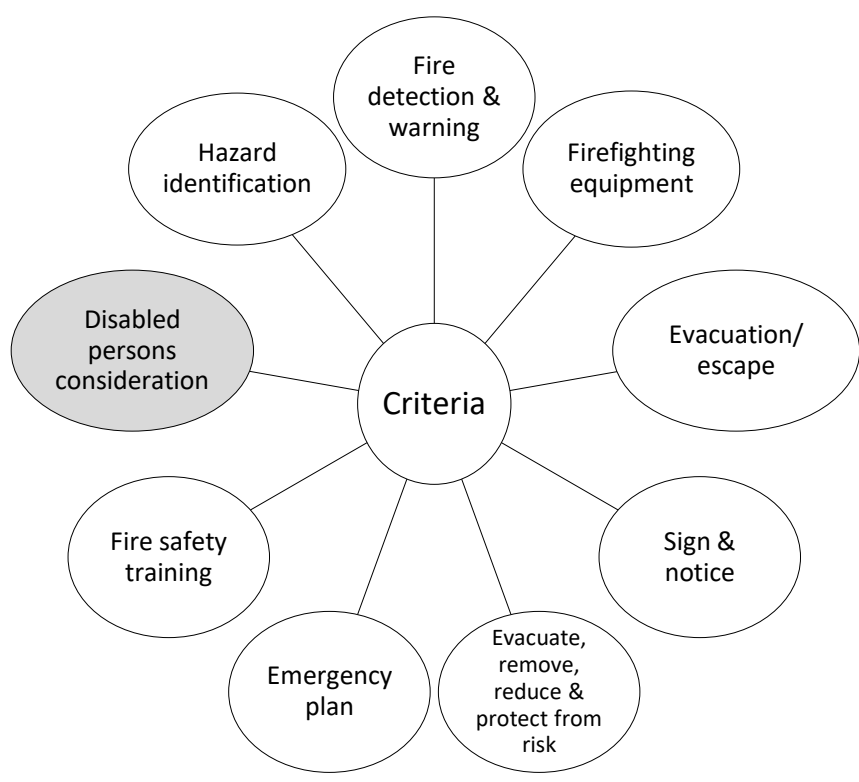

Figure 2: Ten (10) criteria of FRA

Adapted from Department for Communities and Local Government (2006)

Table 2: Probability of fire occurring

\begin{tabular}{|c|c|c|}
\hline Probability & Rating & Description \\
\hline Frequent & 3 & 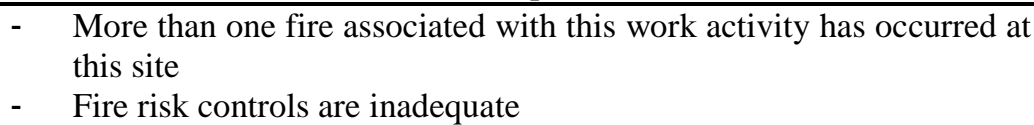 \\
\hline Occasional & 2 & $\begin{array}{ll}\text { - } & \text { A fire has occurred before } \\
\text { - } & \text { Flammables/ combustibles are present } \\
\text { - } & \text { Fire risk controls could be inadequate }\end{array}$ \\
\hline Remote & 1 & 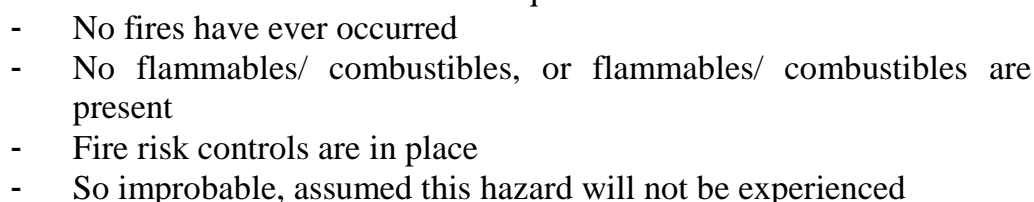 \\
\hline
\end{tabular}

Source: Department for Communities and Local Government (2006); NFPA (2016); Ramachandran (1999)

Table 3: Impact of fire occurrence

\begin{tabular}{|c|c|c|}
\hline Impact & Rating & Description \\
\hline Minor & 1 & 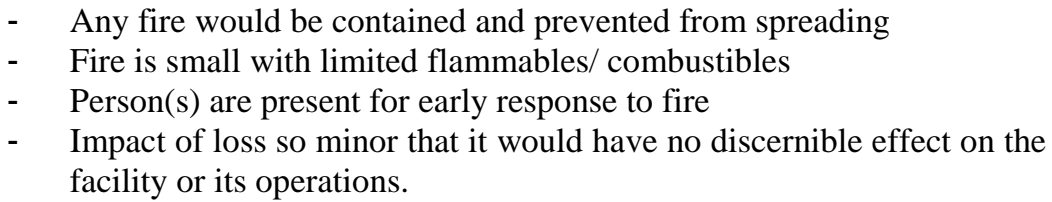 \\
\hline Moderate & 2 & $\begin{array}{l}\text { - Fire can escalate and spread because of flammables/ combustibles } \\
\text { - Person(s) may not be present for early response } \\
\text { - Loss will have impact on the facility, which may have to } \\
\text { suspend some operations briefly. Minor personal injury may be } \\
\text { involved. }\end{array}$ \\
\hline Major & 3 & 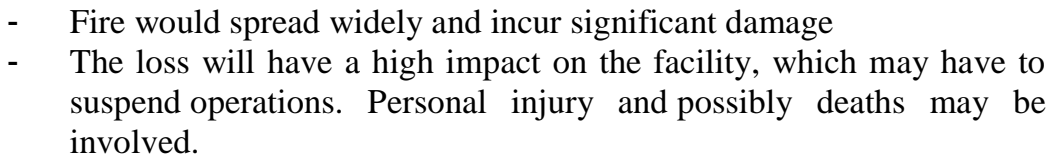 \\
\hline
\end{tabular}

Source: Department for Communities and Local Government (2006); NFPA (2016); Ramachandran (1999) 
Table 4: Matrix evaluation of fire risk level

\begin{tabular}{llll}
\hline Probability/Impact & Minor & Moderate & Major \\
\hline Frequent & Medium & High & High \\
Occasional & Low & Medium & High \\
Remote & Low & Low & Medium \\
\hline
\end{tabular}

Source: Department for Communities and Local Government (2006); NFPA (2016); Ramachandran (1999)

The recommended actions according to respective classification of fire risk level are provided in Table 5.

Table 5: Recommended actions according to fire risk level

\begin{tabular}{|c|c|c|}
\hline $\begin{array}{c}\text { Fire risk } \\
\text { level }\end{array}$ & $\begin{array}{c}\text { Acceptability of fire } \\
\text { risk }\end{array}$ & Recommended actions on fire risk control \\
\hline Low risk & Acceptable & $\begin{array}{l}\text { Take discretionary remedial action: } \\
\text { - } \quad \text { Additional fire risk control measures may not be necessary } \\
\text { - }\end{array}$ \\
\hline $\begin{array}{l}\text { Medium } \\
\text { risk }\end{array}$ & $\begin{array}{l}\text { Moderately } \\
\text { Acceptable }\end{array}$ & $\begin{array}{l}\text { Take remedial action at appropriate time: } \\
\text { - } \quad \text { Evaluation of fire hazards to ensure low fire risk level using } \\
\text { interim fire risk control measures } \\
\text { - } \quad \text { Management attention is required }\end{array}$ \\
\hline High risk & Not acceptable & $\begin{array}{l}\text { Operation not permissible: } \\
\text { - } \quad \text { High risk level must be reduced to at least medium risk before } \\
\text { work commences } \\
\text { - } \quad \text { Eliminate fire hazard if practicable, before work commences } \\
\text { - }\end{array}$ \\
\hline
\end{tabular}

Source: Department for Communities and Local Government (2006); NFPA (2016); Ramachandran (1999)

\subsection{Case study selection and data collection}

Three case study PHP buildings in the Pantai area of Kuala Lumpur were identified for the study. The case studies are identified as PHP Building P, PHP Building Q, and PHP Building R. The first case study, PHP $\mathrm{P}$ is located in Pantai Dalam and provides accommodation mainly for people relocated from squatters in Jalan Ansing, Jalan Kubu and Jalan Pantai Ria. The second case study, PHP $\mathrm{Q}$ is also located in Pantai Dalam and provides accommodation mainly for people relocated from squatter accommodations in Kampung Kerinchi Bukit A and B, Kampung Pasir and Kampung Baru. The third case study, PHP R is located in Lembah Pantai and provides shelter for people relocated from squatter accommodations in Bukit Kerinchi B and C, Jalan Syed Putra and Jalan Klang Lama. All the selected case study PHP buildings had experienced at least one (1) fire incident within the last 5 years, which fulfilled the prerequisite for selection. Since the study involved on-site observations and inspections, the second criteria for case selection was based on accessibility and ease of data collection. The three PHP buildings therefore provided the researchers with adequate accessibility for data collection. First, archival data from the Fire and Rescue Department, Kuala Lumpur, Pantai Fire Station, Kuala Lumpur City Hall (KLCH) was retrieved to obtain data and information about the causes of fire and its origins, maintenance reports of fire safety equipment as well as the background of the buildings and previous fire incidents. This was then followed by a fire safety audit that involved visual onsite non-testing inspections. A 10-item fire risk assessment checklist was utilized to gather onsite data following a 5-stage fire risk assessment framework described in 3.1.1 above in line with the Uniform Building ByLaw 1984 and Fire Service Act 1988 (Act 341) which are the applicable legislation for fire safety in residential buildings in Malaysia as well as other industry guidelines such as the Malaysia Standards MS 1539. One of the shortcomings of this approach is the subjectivity of data (Ramachandran \& Charters, 2011), as such, the competency of the FRA assessors is of even greater importance. Although there is currently no 
certification scheme for fire risk assessors in Malaysia, the research team performing the FRA have expertise in fire safety management with a combined experience of 15 years, and provides fire safety management training to the Fire and Rescue Department of Malaysia. Three (3) assessors performed the fire safety audit over a period of two (2) months. All accessible areas of the case study buildings were investigated with photographs taken as physical evidence of identified fire safety issues. Also, linear measurements were carried out to record dimensions of building components related to fire safety.

\section{RESULTS AND DISCUSSION}

The data obtained through the methods describe in Section 2.3 above was descriptively analysed. Following the checklist criteria, the fire risk status of the case study buildings was collectively computed using the matrix for evaluating fire risk level shown in Table 4. Below, the results are presented.

\subsection{General information of the case study PHP buildings}

Three (3) PHP buildings located in Pantai area were chosen as case study. The profile of the three (3) case study buildings is shown in Table 6. While there is diverse occupancy in the three case study PHP buildings, the population demographics show that overwhelming majority of the occupants are Malay followed by a distant percentage of Indians. For PHP P, all housing units are fully occupied except for one vacant unit in each of Blocks P2 and P3. The facilities provided in PHP P included musolla, grocery, kindergarten, shop office, and library. For PHP
$\mathrm{Q}$, all housing units are fully occupied except one empty unit in each of Blocks Q1 and Q2. The facilities provided in PHP Q included musolla, office, kindergarten, grocery shop, dictionary shop, hair-cutting shop and multipurpose room. And for PHP R all of the housing units are fully occupied except for one vacant unit in Block $R 2$. The facilities provided in PHP $\mathrm{R}$ included the office, kindergarten, musolla, grocery shop, laundry and multi-purpose hall.

Table 6: Profile of all 3 case study PHP buildings

\begin{tabular}{llll}
\hline PHP & $P$ & $Q$ & $R$ \\
\hline Year built & 2007 & 2007 & 1999 \\
Total blocks & 4 & 2 & 2 \\
Total units & 1,264 & 632 & 632 \\
Total households & 1,262 & 630 & 631 \\
Total population & 5,455 & 3,195 & 2,863 \\
Population & & & \\
demographic & & & \\
Malay & $85.63 \%$ & $98.5 \%$ & $84.1 \%$ \\
Chinese & $0.64 \%$ & - & $5.7 \%$ \\
Indian & $13.31 \%$ & $1.5 \%$ & $10.2 \%$ \\
Other & $0.2 \%$ & & \\
\hline & \multicolumn{3}{c}{ Source: KLCH $(2014)$}
\end{tabular}

In Figure 3, a typical layout of a PHP building block is shown. Each building block consists of 17 storeys and 316 dwelling units. The $1^{\text {st }}$ to $14^{\text {th }}$ floor consists of 20 units each while the $15^{\text {th }}$ to $17^{\text {th }}$ floor consists of 12 units each. Three lifts and three staircases are provided including a fire lift located at the centre of each building. Each dwelling unit consist of a living room, a kitchen, a dining room, three bedrooms, a bathroom, a lavatory and a yard as shown in Figure 5.

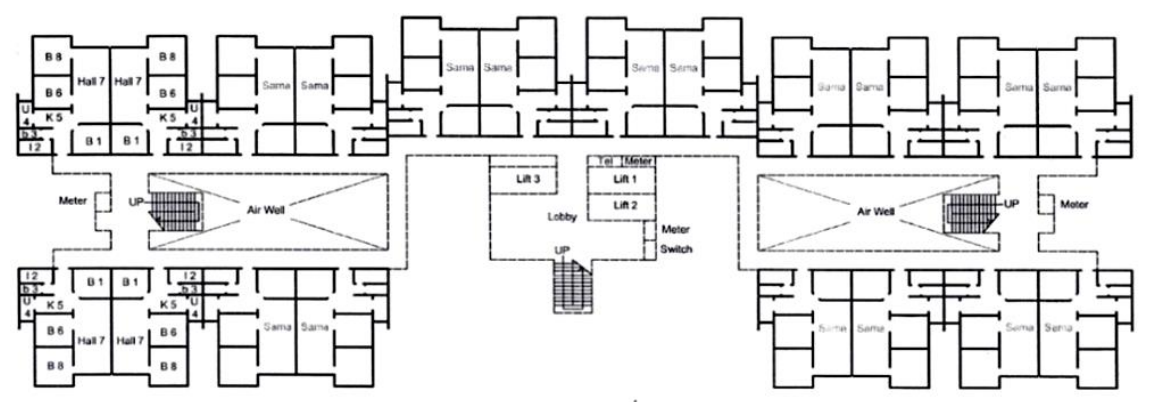

Figure 3: Typical floor plan of the case study PHP buildings

Source: Goh \& Ahmad (2011) 


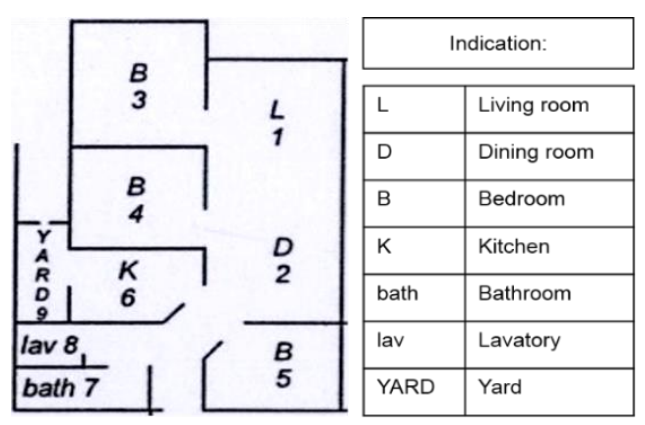

Figure 5: Typical layout of a dwelling unit of the case study PHP buildings Source: Adapted from Goh \& Ahmad (2011)

In Table 7 , the fire safety history is shown. The results show that there were fire cases in all the case study buildings with every building block recording at least one fire case. It amounted to a total of 10 fire cases in three years $(2012,2013$, and 2014) with six of the fire incidents occurring in the year 2013. PHP $\mathrm{P}$ had the most fire incidents with a total of 5 fire cases.

Table 7: The number of fire cases

\begin{tabular}{llll}
\hline PHP & Block & Year & Fire Cases \\
\hline P & P1 & 2013 & 1 \\
& P2 & 2013 & 1 \\
& P3 & $2013 \& 2014$ & 2 \\
& P4 & 2013 & 1 \\
Q & Q1 & 2013 & 1 \\
& Q2 & 2013 & 1 \\
R & R1 & $2012 \& 2014$ & 2 \\
& R2 & 2014 & 1 \\
\multicolumn{1}{c}{ Total } & & & $\mathbf{1 0}$ \\
\hline
\end{tabular}

Source: KLCH (2014)

\subsection{Leading causes of fires in PHP buildings in Pantai area}

Open flames and failure of electrical wiring systems were the main causes of fires in PHP buildings in the Pantai area as shown in Figure 6. Figure 6 shows a downward trend in fire occurrences over the observed years. While open flames and failure of electrical wiring systems were responsible for equal number of fire cases in 2011 and 2012 causing four (4) fires each, in 2013 and 2014, open flames were responsible for more fire.

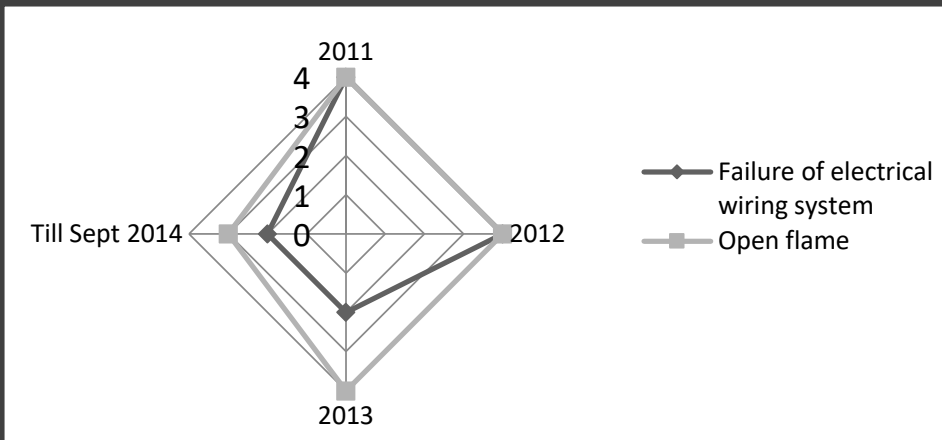

Figure 6: Causes of fires in PHP buildings in Pantai area from year 2011 to Sept 2014

Source: Compiled from FRDKL fire incidents reports 


\section{.2.1 Rooms of fire origin in PHP buildings in Pantai area}

In Table 8, the rooms of fire origin in PHP buildings in Pantai area are shown. When aggregated, the living room, bedroom, dining room, bathroom and yard accounted for about
$64 \%$ of the origin of fire, while the kitchen accounted for about $27 \%$ of the fire cases. The figures in the table below show the kitchen appearing to be the single location with the highest number of fire cases.

Table 8: Fire origins in PHP buildings in Pantai area from 2011 to Sept 2014

\begin{tabular}{|c|c|c|c|c|c|}
\hline \multirow{2}{*}{ Rooms of fire origin } & \multicolumn{4}{|c|}{ Number of fires } & \multirow[b]{2}{*}{ Total } \\
\hline & 2011 & 2012 & 2013 & Till Sept 2014 & \\
\hline $\begin{array}{l}\text { House (other than kitchen and } \\
\text { storeroom) }\end{array}$ & 1 & 3 & 7 & 3 & 14 \\
\hline Kitchen & 1 & 1 & 2 & 2 & 6 \\
\hline Garbage house & - & 1 & - & - & 1 \\
\hline Storeroom & - & - & 1 & - & 1 \\
\hline Total & 2 & 5 & 10 & 5 & 22 \\
\hline
\end{tabular}

\subsubsection{Sources of fuel in PHP buildings in Pantai area}

Table 9 shows the fuel sources of previous fires in PHP buildings in Pantai, the study area.
It shows garbage as the main fuel source, responsible for four (4) fire cases, followed by bush, responsible for three (3) within a period of less than 4 years.

Table 9: Fuel sources of fire incidents in PHP buildings in Pantai area from year 2011 to Sept 2014

\begin{tabular}{lccccc}
\hline & \multicolumn{2}{c}{ Number of fires } & & \\
\cline { 2 - 6 } \multicolumn{1}{c}{ Sources of fuel } & 2011 & 2012 & 2013 & Till Sept 2014 & Total \\
\hline Garbage & 2 & - & 2 & - & 4 \\
Sink & 1 & - & - & - & 1 \\
Electrical cable & 1 & - & 1 & - & 2 \\
Textile & - & 1 & - & - & 1 \\
Toilet flushing tank & - & 2 & - & - & 2 \\
Stacked Boxes & - & 2 & - & - & 2 \\
Bush & - & - & 1 & 2 & 3 \\
Tire & - & - & 1 & - & 1 \\
Motorcycle & - & - & 1 & - & 1 \\
Mattress & - & - & - & 1 & 1 \\
Garbage Truck & - & - & - & 1 & 1 \\
Cooking stove & - & - & - & 1 & 1 \\
Refrigerator & - & - & - & 1 & 21 \\
\multicolumn{1}{c}{ Total } & 4 & 5 & 6 & 6 & 1 \\
\hline
\end{tabular}

Source: Compiled from Pantai Fire Station fire incidents reports

\subsection{Results from fire audit}

The fire audit of the case study buildings was performed through an on-site visual inspection that followed a 10-item FRA checklist to gather fire safety data. Issues were found in all of the 10-fire risk assessment checklist items. The results of the visual inspections are described below according to the 10-item checklist.

\subsubsection{Presence of potential ignition and fuel sources}

The list of potential ignition sources and potential fuel sources are shown in Table 10. The results show that majority of the ignition sources are electrical installations while the potential fuel sources are almost entirely household items (see Figures 7 and 8). As 
shown in Figures 8 and 9, it can be seen that the potential of, especially fuel sources, is enhanced by poor housekeeping as items are cluttered and stuffed haphazardly.

Table 10: The potential ignition sources and fuels present in the building

\begin{tabular}{|c|c|}
\hline Location & Potential ignition sources \\
\hline Dwelling unit & $\begin{array}{l}\text { Fluorescent lights, electrical extension, switchboard, cooking stove, oven, cooking } \\
\text { gas, water heater, incense, electrical wiring of extension plugs }\end{array}$ \\
\hline Corridor & Burning oil lamp \\
\hline Location & Potential fuel sources \\
\hline Dwelling unit & $\begin{array}{l}\text { Decorating items, blanket, mattress, sofa, luggage, clothes, doll, clothes shelf, vase, } \\
\text { cabinet, hand phone chargers, calendars, etc. }\end{array}$ \\
\hline Corridor & $\begin{array}{l}\text { Hanging clothes, plastic chairs, cabinet, potted plant, shoes, wheel barrow, blanket, } \\
\text { garbage, timber tables, refrigerator, vase, cabinet, boxes, timber chair, washing } \\
\text { machine, carpet, garbage, cushion chair, shoe rack, sofa, etc. }\end{array}$ \\
\hline $\begin{array}{l}\text { Fire-fighting } \\
\text { equipment room }\end{array}$ & $\begin{array}{l}\text { Bicycle, garbage, backpack, helmet, basket, water bottle, bucket, pot, fertilizer, } \\
\text { steel net, plastic chairs, generator, boxes, trolley, water bottles, timber board, } \\
\text { cooking pan, etc. }\end{array}$ \\
\hline
\end{tabular}

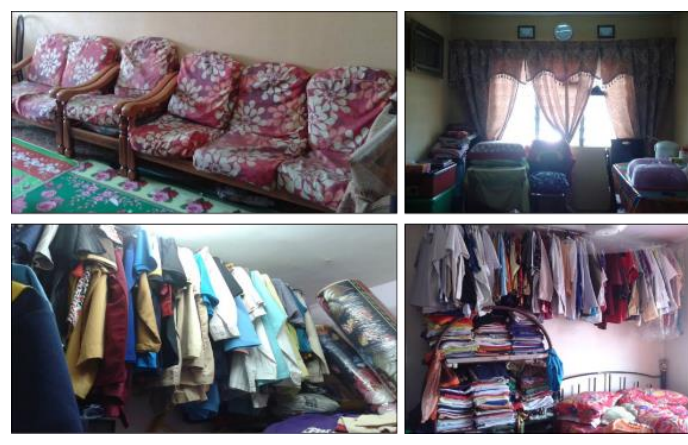

Figure 7: Potential fuel sources in the living room and bedroom

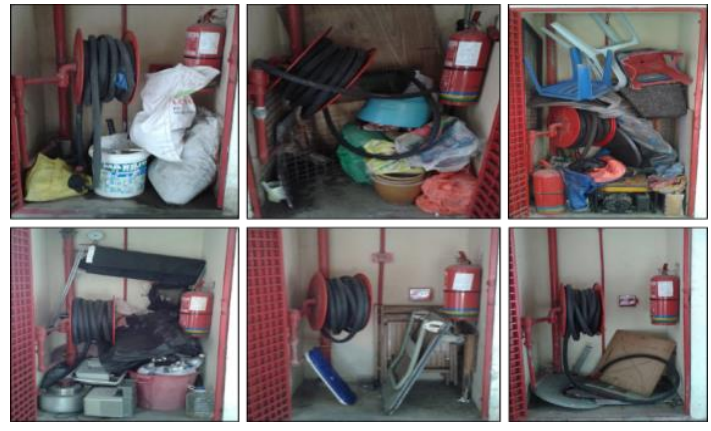

Figure 8: Potential fuel sources in the firefighting equipment room

\subsubsection{Insufficient and vandalized smoke detectors, manual call points and fire alarm}

A smoke detector is provided only in the centre lift lobby of PHP P and Q while three (3) sets of manual call point and fire alarm can be found only on the $5^{\text {th }} 10^{\text {th }}$ and $15^{\text {th }}$ floors of each block of PHP P and Q. At PHP R, there is no smoke detector or a complete set of manual call points and fire alarms. Figure 9 show the vandalized smoke detectors and manual call points.

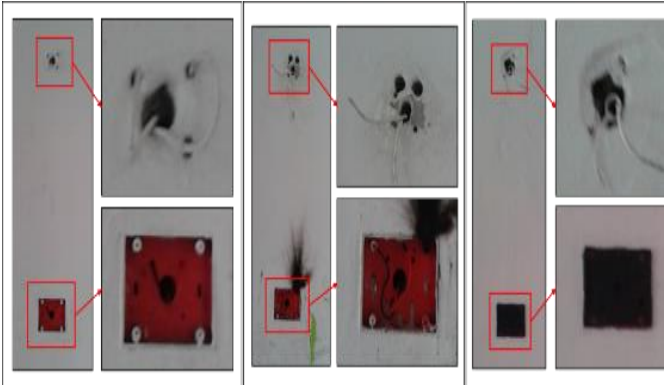

Figure 9: Vandalized manual call points and fire alarm

\subsubsection{Inaccessibility to fire-fighting room, vandalized hose reels and missing fire extinguishers}

Approximately $80 \%$ of the fire-equipment rooms in all the case study PHP buildings were locked and inaccessible during inspection. In addition, clutter blocked the access to firefighting equipment room (see Figure 10). There also were vandalized hose reels with missing or broken valves and nozzles as well as missing portable fire extinguishers as shown in Figure 11. 


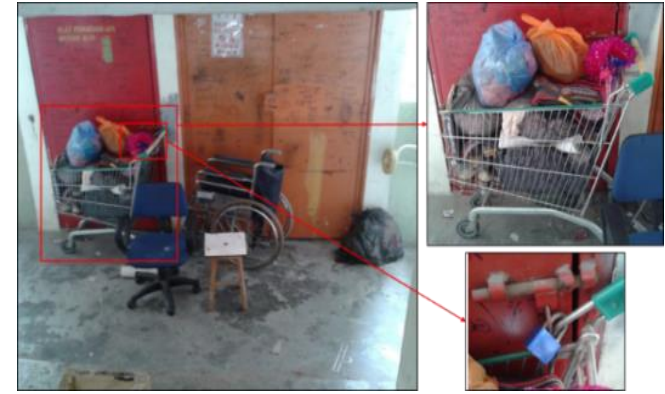

Figure 10: Trolley, chair and wheelchair blocking access to fire-fighting equipment

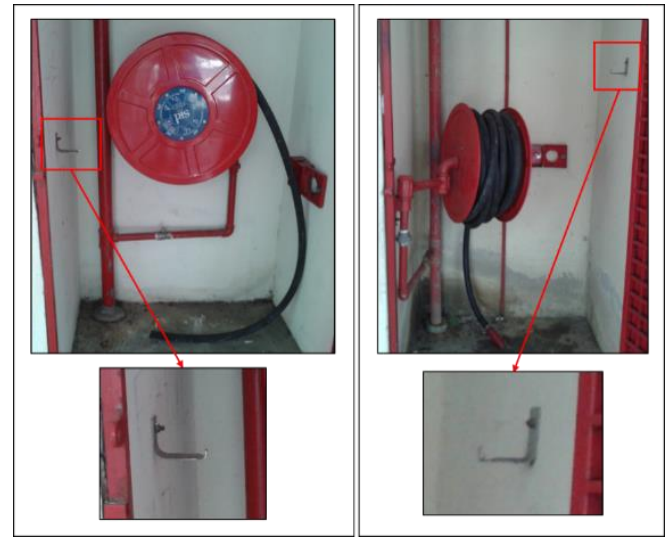

Figure 11: Missing portable fire extinguishers

It was also found that some of the hose reel locks were broken by the building users in order to get water for daily use when water supply to their units was cut off due to water crisis, maintenance of water pumps, and rents default. According to By-Law 225(2) of the Uniform Building By-Law 1984, every building must have at least one fire hydrant at a distance equal or not exceeding 45 meters from the closest location of fire hydrant. It was, however found that, the distance between two fire hydrants in PHP Q was 153.80meters. PHP R, Block R2 did not have a fire hydrant at all, thus resulting in non-compliance with ByLaw 225(2).

\subsubsection{Obstructed escape routes}

Findings show that all the case study buildings had the recommended minimum corridor width of $1,542 \mathrm{~mm}$, however, as shown in Figure 12the corridors were cluttered with household items. This narrowed the width of the travel pathway and will be an obstruction in the event of emergency and mass egress.
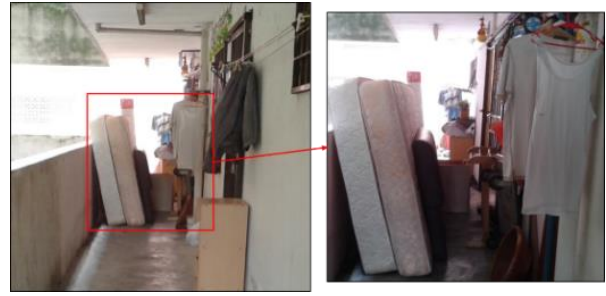

Figure 12: Escape route blocked by mattresses and other items

Emergency lighting was also found to be inadequate. The emergency light is provided only at the left, centre and right sides of each PHP building except PHP P which is provided with emergency light only on ground floor. There was no emergency lighting along the corridors in any of the observed case study buildings. During any disruption of electricity supply in the event of a fire, the current emergency lighting would be insufficient to adequately light the exit pathways. Furthermore, there was no maintenance record of emergency light in all the case study PHP buildings, thus raising questions to whether they were in good working condition and capable of effectively functioning in the event of a fire emergency.

\subsubsection{Insufficient, vandalized and non- illuminated emergency exit signs}

There were inadequate emergency exit signs in all the case study buildings because most of the signs were vandalized (see Figure 13). Also, none of the emergency exit signs in the case study buildings were illuminated, a noncompliance with By-Law 172(4). Also, some of the indication signs were stripped off and covered with graffiti, making them illegible as shown in Figure 14. Installed fire-fighting equipment also had no designated signage. In Figure 15, there is no signage designating firefighting equipment thus not complying with By-Law 248 (2) of the Uniform Building ByLaw 1984 and MS 1539.
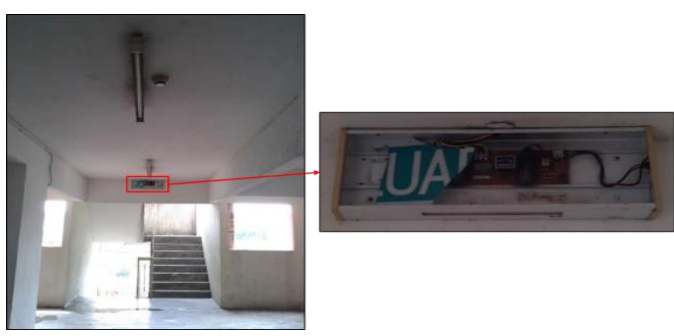

Figure 13: Vandalized emergency exit sign 


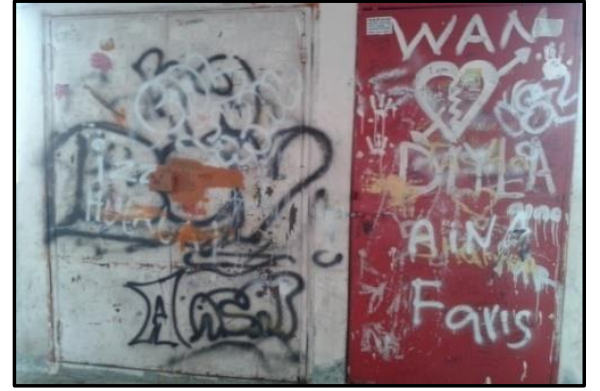

Figure 14: Fire indication sign covered by graffiti
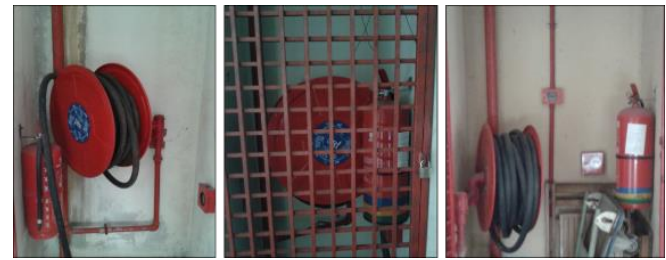

Figure 15: No provision of fire safety sign for each fire extinguisher

\subsubsection{No maintenance record of firefighting equipment}

It was found that maintenance report of smoke detector, emergency exit sign and emergency light did not exist. The maintenance department of the case study buildings did not have records of maintenance activities and servicing carried out on the installed firefighting equipment. This means that the functionality of the equipment in the event of a fire emergency was uncertain as the condition of the equipment was not known.

\subsubsection{Scattered garbage around the lift lobby, stairwell and garbage house}

Although it was found that cleaning was performed every day, there was still garbage in common areas such as stairwells and lift lobbies at all the case study buildings (see Figure 16)
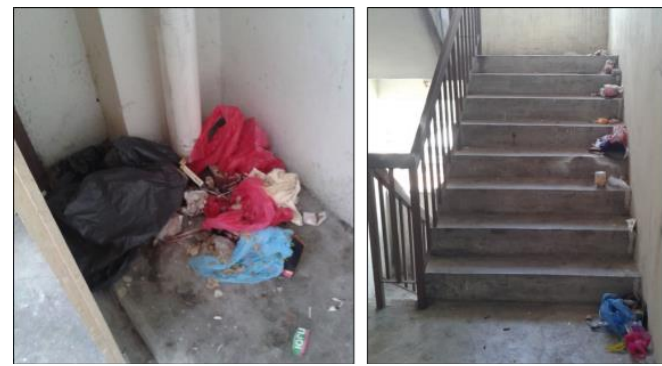

Figure 16: Garbage scattered around lift lobby and staircase
4.3.8 Lack of an emergency plan and designated emergency assembly point

It was found that none of the PHP buildings had an emergency evacuation plan or emergency action plan. There was also only one nominated block representative who acted as a "bridge" for the occupants and the Residents' Association and occupants. The responsibility of the representative is to notify the occupants of emergency situations. However, neither the occupants nor workers (cleaners) had been notified of any hazards in and around the case study buildings. While this could suggest that the nominated block representative had not been performing his/her duties appropriately, it exposes the inadequacy of the provision of nominated block representatives. By guideline and regulations, there should be one nominated representative for each floor of each block.

\subsubsection{Occupants lack fire safety training}

The building occupants were found to have no adequate knowledge of what to do in the event of a fire despite the maintenance personnel having the knowledge of dealing with fire in emergency situations. It was also found that, there has never been an evacuation/fire drill in any of the case study buildings. As a result, there was no record of any instruction as well as the details of cooperation and coordination with the others in a simulated scenario.

\subsubsection{Little consideration for disabled persons}

While ramps for disabled persons were provided in two of the case study buildings, none of the ramps were provided with handrails (see Figure 17).
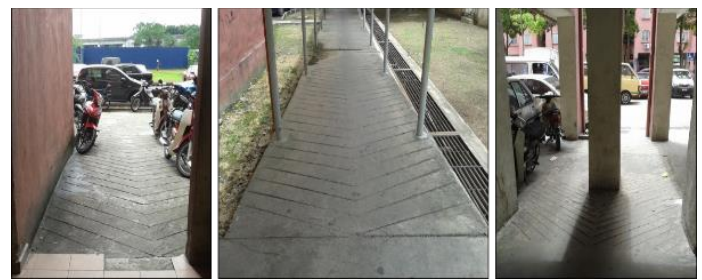

Figure 17: Ramps without handrails

Also, neither guiding block nor embossed marks were found on any of the staircases and handrails of all the case study buildings. Measurements performed indicated that the staircase risers were not uniform in height with 
differences in the tallest and shortest riser up to $54 \mathrm{~mm}$ (see Figure 18). There were also no guiding blocks on any of the staircases at the case study buildings. Braille or embossed lettering was also not provided on any of the lift car buttons in any of the case study buildings (see Figure 19).

\subsection{Determining fire risk status of the case study buildings}

In Table 11, a summary of the findings is presented while Table 12 shows the computation of the fire risk status of the case study buildings. As shown in Table 12, the fire risk status of the observed case study buildings is high and has reached 'unacceptable' level.

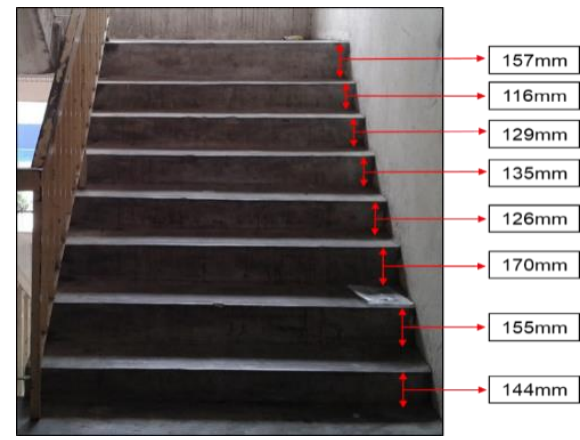

Figure 18: Inconsistent riser heights and no guiding block

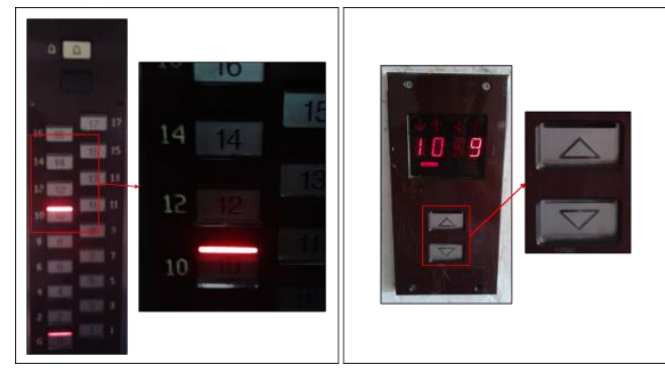

Figure 19: No Braille on any of the lift car buttons

\section{DISCUSSION AND CONCLUSION}

This research has established that the fire risk level in the observed PHP buildings is very high, reaching the 'unacceptable' fire risk level. As noted in Table 12 above, the high fire risk level in the observed case study buildings is a result of inadequacy of both active and fire safety protections systems. While it was found that the design and installation of fire safety protection systems was foremost inadequate, installed and existing systems were found to be largely vandalized and barely functional. The lack of fire safety training for building occupants and users and enforcement of existing regulations such as fining vandals allowed them to break simple fire safety guidelines such as cluttering escape routes, been careless with fuel and fire ignition sources, and vandalising fire fighting equipment with impunity. Lack of knowledge regarding the importance of fire prevention and fire protection practice as well as poor fire risk management poses higher chances of fire occurrence rate and cause greater injury, fatality and loss of property during a fire. The inadequate or lack of fire safety awareness among building occupants is thus a concern that requires immediate solution. The findings from this study supports Yatim (2009) who contended that there is higher fire risk hazard in high-rise buildings due to factors such as the diverse demographics (different cultural and educational backgrounds) of building occupants. In the observed case study buildings, it was found that, not only the building occupants were from relatively different cultural and educational backgrounds, but the occupant density was also very high. There is therefore need for immediate intervention to reduce the high fire risk level of the observed case study buildings.

To begin, the existing building design of PHP buildings do not provide optimum level of fire safety with adequate room for improving fire safety performance of the buildings. The existing design layout of the dwelling units is the most significant building engineering issue. For instance, the location of the kitchen alongside the entrance to the house raises efficient evacuation concerns in the event of a fire in the kitchen as it was found to be the location within the building with the highest number of fire ignition sources and flammable materials. There is therefore a higher probability of a fire beginning in the kitchen. With the current layout, a large fire in the kitchen makes it near impossible for the building occupants within the dwelling unit to escape because the only exit out of the house would be obstructed by fire. 
Table 11: Summary of FRA of the case study buildings

\begin{tabular}{|c|c|c|}
\hline No. & Criteria & Issues identified \\
\hline 1 & Hazard identification & High potential ignition and fuel sources \\
\hline 2 & $\begin{array}{l}\text { Fire detection and warning } \\
\text { system }\end{array}$ & $\begin{array}{l}\text { Inefficient and vandalised smoke detector, manual call } \\
\text { point and fire alarm }\end{array}$ \\
\hline 3 & Fire-fighting equipment & $\begin{array}{l}\text { Fire-fighting room not accessible, vandalized hose } \\
\text { reels, missing portable fire extinguishers and } \\
\text { insufficient fire hydrants }\end{array}$ \\
\hline 4 & Evacuation/escape & $\begin{array}{l}\text { Cluttered escape routes and insufficient emergency } \\
\text { lights }\end{array}$ \\
\hline 5 & Sign and notice & $\begin{array}{l}\text { Emergency exit signs vandalised and not illuminated. } \\
\text { Fire safety sign for installed fire-fighting equipment } \\
\text { not provided }\end{array}$ \\
\hline 6 & Recording & $\begin{array}{l}\text { No maintenance record for smoke detector, emergency } \\
\text { exit signs and emergency lights. }\end{array}$ \\
\hline 7 & $\begin{array}{l}\text { Evaluation, removal, reduction } \\
\text { and protection from risks }\end{array}$ & $\begin{array}{l}\text { Stairwell, lift lobby and garbage house littered and } \\
\text { cluttered with garbage }\end{array}$ \\
\hline 8 & Emergency plan & $\begin{array}{l}\text { No emergency plan and designated emergency } \\
\text { assembly point }\end{array}$ \\
\hline 9 & Fire safety training & $\begin{array}{l}\text { Building occupants lack fire safety knowledge due to } \\
\text { lack of training. Evacuation/fire drill has never been } \\
\text { conducted in any of the buildings }\end{array}$ \\
\hline 10 & Disabled persons consideration & $\begin{array}{l}\text { Very little consideration for disabled person's needs. } \\
\text { Ramps do not have handrails; no guiding blocks on } \\
\text { staircases. Riser heights are inconsistent. No Braille on } \\
\text { lift buttons }\end{array}$ \\
\hline
\end{tabular}

Table 12: Fire risk status of the case study buildings

\begin{tabular}{|c|c|c|c|c|c|c|}
\hline \multirow{2}{*}{$\begin{array}{l}\text { FRA } \\
\text { criteria }\end{array}$} & \multirow[t]{2}{*}{ Probability (p) } & \multirow{2}{*}{$\begin{array}{l}\text { Impact } \\
\text { (i) }\end{array}$} & \multicolumn{2}{|l|}{ Rating } & Score & \multirow{2}{*}{$\begin{array}{l}\text { Risk } \\
\text { status }\end{array}$} \\
\hline & & & $\mathbf{p}$ & i & (p) $\times(i)$ & \\
\hline 1 & $\mathrm{~F}$ & $\mathrm{M}$ & 3 & 3 & 9 & High \\
\hline 2 & $\mathrm{~F}$ & M & 3 & 3 & 9 & High \\
\hline 3 & $\mathrm{~F}$ & M & 3 & 3 & 9 & High \\
\hline 4 & $\mathrm{~F}$ & M & 3 & 3 & 9 & High \\
\hline 5 & $\mathrm{~F}$ & M & 3 & 3 & 9 & High \\
\hline 6 & $\mathrm{~F}$ & M & 3 & 3 & 9 & High \\
\hline 7 & $\mathrm{~F}$ & M & 3 & 3 & 9 & High \\
\hline 8 & $\mathrm{~F}$ & M & 3 & 3 & 9 & High \\
\hline 9 & $\mathrm{~F}$ & M & 3 & 3 & 9 & High \\
\hline 10 & $\mathrm{~F}$ & $\mathrm{M}$ & 3 & 3 & 9 & High \\
\hline
\end{tabular}

Secondly, the fire safety systems in all of the dwelling units of the observed PHP buildings require immediate upgrade, taking into consideration also the needs of physically challenged persons. The kitchen areas for instance need to be installed with fire blankets hence it was the location within the unit more prone to a fire occurrence. There is however, no legislation mandating the installation of fire blankets, but fire blankets are useful active fire safety equipment effective in putting out as well as containing small fires (Fire Industry Association, 2011). On the other hand, the Tenth Schedule of the UBBL 1984 requires that a minimum of one portable fire extinguisher be installed in each dwelling unit. Strict enforcement of this By-Law would ensure that minimum fire safety requirements are achieved in this regard. Also, it is suggested that some form of automatic early fire detection and warning system e.g. selfcontained devices like smoke and heat alarm be installed in areas such as the bedrooms, living rooms, dining rooms, etc. Zhang \& Wong (2009) note that this system has been well implemented in residential buildings and has proven effective in reducing loss of life and property in the event of fires. And although the Fire Services Act 1988 (Act 341) exempt isolated private dwellings from having 
a fire certificate, PHP buildings should not be exempt from this requirement considering the population and demographics of high rise low cost residential buildings. As noted earlier, these types of buildings have the highest fire incidents compared to other types of residential building. With numerous fire hazards as well, it is safe to say that the occupants of these buildings are exposed to high fire risks. As described by the Fire Services Act 1988 (Act 341), the fire certificate requirement is to ensure designated buildings are equipped with sufficient fire prevention, fire protection and fire-fighting equipment (Laws of Malaysia, 2006).

To add, the building management should design and implement a preventive maintenance regime in order to make sure that existing fire safety equipment are in optimal working condition. There is also need for designing and implementation of an emergency evacuation and action plan that will clearly instruct building occupants and users on evacuation operations and routes and provision of an emergency assembly point.

Finally, the fire safety knowledge and awareness of the building occupants need immediate enhancement. The building occupants usually would be the first responders to a fire in the building and do not only require knowledge of fire prevention but also need knowledge on how to appropriately respond in the event of fire. Building occupants can only be equipped with knowledge about fire safety and awareness through adequate training such as fire drills/evacuation exercises. It is worthy to note that Fire and Rescue Department, Kuala Lumpur and Kuala Lumpur City Hall had worked together to establish Fire Community Firefighter Squad in every PHP buildings to disseminate the importance of fire prevention systems and prevent vandalism of fire safety and firefighting equipment. Effective implementation of these initiatives would contribute greatly to encourage duty of care in terms of fire safety and fire prevention among building occupants of PHP buildings.

\section{ACKNOWLEDGEMENT}

This work was supported by the Ministry of Higher Education, Malaysia through the FRGS Grant (Grant No.: FP046-2014B) and University of Malaya (Grant No.: BK0242011B). Special thanks to the Fire and Rescue
Department of Malaysia for granting this study the permission to access fire investigation reports and to all the officers for their support during data collection.

\section{REFERENCES}

Aini, A. M., Murni, N., \& Aziz, W. N. A. W. A. (2016). Housing Aspirations of the Elderly in Malaysia: A Comparison of Urban and Rural Areas. Journal of Design and Built Environment, 17(2), 30-43.

Billington, M. J., Copping, A. G., \& Ferguson, A. (2008). Means of escape from fire. UK: Blackwell Science.

Chu, G. Q., Chen, T., Sun, Z. H., \& Sun, J. H. (2007). Probabilistic risk assessment for evacuees in building fires. Building and Environment, 42(3), 1283-1290. doi:10.1016/j.buildenv.2005.12.002

Craighead, G. (2009). High-rise security and fire life safety. New York: Elsevier.

Dawkin, A. (2001). Fire risk management in heritage buildings. Building Engineer, 76(7), 14-15.

Department for Communities and Local Government. (2006). Fire safety risk assessment - residential care premises. London: Department for Communities and Local Government.

Ramachandran, G. (1999). Fire safety management and risk assessment. Facilities, 17(9/10), 363-377.

Ramachandran, G., \& Charters, D. (2011). Quantitative risk assessment in fire safety. Oson, Oxford: Spon Press.

Goh, A. T., \& Ahmad, Y. (2011). Public LowCost Housing in Malaysia: Case Studies on PPR Low-Cost Flats in Kuala Lumpur. Journal of Design and the Built Environment, 8(1).

Fire and Rescue Department of Malaysia. (2016). Fire and Rescue Department of Malaysia Annual Reports. Retrieved from http://www.bomba.gov.my

Fire Industry Association. (2011). Code of practice for the commissioning and maintenance of fire blankets manufactured to BS EN 1869. Hampton: Fire Industry Association.

International Code Council. (2009). International Building Code 2009. U.S.A.: International Code Council, Inc.

Hall, J. R. (2013). High-rise building fires. Quincy: National Fire Protection Association, fire Analysis and Research Division. 
Kaplan, M. E., \& Watts, J. M. (2001). Fire risk index for historic buildings. Fire Technology Journal, 37, 167-180.

Kobes, M., Helsloot, I., Vries, B. V., \& Post, J. G. (2010). Building safety and human behaviour in fire: A literature review. Fire Safety Journal, 45(1), 1-11. doi:10.1016/j.firesaf.2009.08.005

Kuala Lumpur City Hall. (2008). Draft Kuala Lumpur City Plan 2020. Kuala Lumpur: National Malaysia Printing Ltd.

Laws of Malaysia. (2006). Fire Services Act 1988 (Act 341). Putrajaya: The Commissioner of Law Revision, Malaysia.

Laws of Malaysia. (2012). Uniform Building By-Laws 1984 (Amendment 2012) (Act 133). Putrajaya: The Commissioner of Law Revision, Malaysia.

Ministry of Housing, Spatial Planning, and the Environment, Netherlands. (2005). Sustainable refurbishment of high-rise residential buildings and restructuring of surrounding areas. Report for European Housing Ministers' Conference. Czech Republic: Ministry of Housing, Spatial Planning, and the Environment, Netherlands.

National Fire Protection Association. (2016). NFPA 551: Guide for the Evaluation of Fire Risk Assessments 2007 Edition. Quincy, MA: NFPA

National Housing Department. (2010). National housing policy. Damansara Town Centre: Ministry of Housing and Local Government.

Reyers, J. (2003). Risk and liability of consultants advising on built heritage. Structural Survey Journal, 21, 8-15.

Solomon, P. E. R., \& Harrington, P. E. G. (2003). Building construction and safety code handbook: Quincy, MA: NFPA International.

The Economic Planning Unit. (2010). Tenth Malaysia Plan. Putrajaya: The Economic Planning Unit, Prime Minister's Department.

Yatim, Y. M. (2009). Fire safety models for high-rise residential buildings in Malaysia. (Degree of Doctor of Philosophy), HeriotWatt University, Edinburgh.

Yung, D. (2008). Principles of fire risk assessment in buildings. Chichester: A John Wiley and Sons, Ltd.

Zhang, L., \& Wong, G. F. (2009). Design and implementation of automatic fire alarm system based on wireless sensor networks. Proceedings of the 2009 International Symposium on Information Processing (pp.
410-413). Huang Shan: Academic Publisher. 

al. 